\title{
Social and Psychological Features of Crime Groupings
}

\section{Características sociales y psicológicas de las agrupaciones delic- tivas}

\section{Flera Gabdulbarovna Mukhametzyanova}

Archaeographic Laboratory Institute of International Relatons, Kazan Federal University, Russia

ORCID: https://orcid.org/0000-0001-9991-1549

Aleksey Nikolaevich Gryaznov

University of Management "TISBI", Russia

ORCID: https://orcid.org/0000-0001-7959-4208

\section{Elena Olegovna Chernova}

Institute of Pedagogy, Psychology and Social Problems, Russia

ORCID: https://orcid.org/0000-0002-6714-4936

\section{Adelya Ilhamovna Sattarova}

Institute of International Relatons, Kazan(Volga Region) Federal University, Russia

ORCID: https://orcid.org/0000-0003-1060-3393

\section{Lucia Ravilevna Ibragimova}

Center for Successful Development and Education "Vzroslyye deti", Russia Adolescent Psychological and Correctional Center "Vremya pervyh", Russia

ORCID: https://orcid.org/0000-0003-3077-7147

Received 06-14-20 Revised 08-10-20 Accepted 09-01-20 On line 09-30-20

*Correspondence

Email: florans955@mail.ru
Cite as:

Mukhametzyanova, F.G., Gryaznov, A.N., Chernov, E.O., Sattarova, A.I., Ibragimova, L.R. (2020). Social and Psychological Features of Crime Groupings. Propósitos y Representaciones, 8 (SPE3), e759. Doi: http://dx.doi.org/10.20511/pyr2020.v8nSPE3.759 


\section{Summary}

The article reveals the potential of implementation of different theories in the process of creation of the complex methodology of the research of social and pedagogical features of the members of teenager-youth street crime groupings (gangs). The author creates the design of indicative model allowing to notice the condition of social and adaptive potential of the personality of teenage youth: motivation for behavior and actions, reflexive abilities, value- meaning sphere and the level of the behaviour aggression. The author concludes that there is a necessity to determine subjective potential of the teenage youth personality, who are the members of gangs for designing the system of preventive measures against involvement them in the gangs and further successful social adaptation and socialization after quitting the gang. The author concludes that the obtained data can be the basis for the development of preventive measures in the process of working with the teenagers from the risk group.

Keywords: social and psychological features, juvenile delinquency, social and adaptive potential of the personality of a teenager, socialization, social adaptation, social and psychological research.

\section{Resumen}

El artículo revela el potencial de implementación de diferentes teorías en el proceso de creación de la compleja metodología de investigación de las características sociales y pedagógicas de los integrantes de agrupaciones (pandillas) de delincuencia callejera adolescente-juvenil. El autor crea el diseño de modelo indicativo que permite advertir la condición de potencial social y adaptativo de la personalidad de la juventud adolescente: motivación para comportamientos y acciones, habilidades reflexivas, ámbito de valor-significado y nivel de la conducta agresiva. El autor concluye que existe la necesidad de determinar el potencial subjetivo de la personalidad de los jóvenes adolescentes, que son los integrantes de las pandillas, para diseñar el sistema de medidas preventivas contra su participación en las pandillas y una mayor adaptación social y socialización exitosa después de dejar la pandilla. El autor concluye que los datos obtenidos pueden ser la base para el desarrollo de medidas preventivas en el proceso de trabajo con los adolescentes del grupo de riesgo.

Palabras clave: rasgos sociales y psicológicos, delincuencia juvenil, potencial social y adaptativo de la personalidad de un adolescente, socialización, adaptación social, investigación social y psicológica.

\section{Introduction}

In the modern Russian society, a number of negative social phenomena are caused by socioeconomic, spiritual and moral changes.

The economic development of a country largely depends on the level of its automation and robotization. Innovations and new technologies are key factors in sustainable economic growth in the modern global economy (Khairutdinov et al., 2018). One of the most serious problems is the rise in juvenile delinquency. This phenomenon must be regulated for university students to develop their creativity. Creativity as a capacity for creativity is the leading criterion for the success of the development of the individual as a subject of learning (Mukhametzyanova et al., 2017). One of the most serious problems is the growth of juvenile delinquency. A strong ambition and desire to increase status in the micro-social environment along with social illbeing stimulate involvement of teenage youth in the street criminal groupings (gangs). The involvement of teenage youth in such non-formal groupings, in its turn, leads to a violation of the 
normative nature of their social adaptation and contributes to the formation of their "criminal career". In this regard, an in-depth and comprehensive study of the socio-psychological features of teenage youth involved in the street criminal groupings (gangs) is an important factor for the prevention of disadaptation and the development of further social deviations of members of youth street crime groupings.

According to the author's opinion, the specific feature of the studied problem is that, on the one hand, there are many separate studies on the problems of criminalization of the teenage youth environment; on the other hand, it should be noticed that there is lack of a unified, complex conception in this theoretical field of the research.

At this stage of the research, we have made an attempt to develop a methodology for the study of socio-psychological characteristics of members of groupings: basic theoretical approaches, criteria and factors of participation of teenage youth in groupings are defined, methodological tools and research procedure are developed. As the main groups of factors influencing the involvement of teenage youth in groupings, we consider objective (the impact of the environment and micro-environments) and subjective (personal characteristics). Both groups are closely inter-related: external conditions form personal characteristics in the process of socialization of teenage youth, but a number of qualities are inherent in the personality.

Mentioned above characteristics of groupings correspond to their special systems, functioning on the principles of the systems, while the relationship between their members is determined due to the socio-psychological mechanisms of development of these systems. This implies a systematic analysis of groupings. The purpose of this analysis is the search for a set of indicators (psycho-markers) for the members of groupings in order to build an effective model of preventive measures through the impact on the process of socialization of teenage youth. Our scientific opinion is based on several macro-indicators of features of teenage youth-members of groupings: they are first of all, value and semantic orientation and factors of social relations; secondly, social and adaptive potential; thirdly, the subjective characteristics of the personality of teenage youth (the degree of development of the criteria "motivation of achievement"); fourthly, reflective characteristics of teenage youth.

Subjectivity as an interdisciplinary category is actively studied today by representatives of various fields of scientific knowledge. First of all, the formation of civil society in modern Russia determines the need for understanding the place and role of the individual as a subject in the social space. In addition, an increase in existential risk also necessitates an understanding of subjectivity as a hypostasis of the individual - how, in what ways is the person able to confront the individual with the emerging risks (Ilikova, 2016). Here you can also talk about xenophobia and ethnic nationalism, which accompany each other, they can precede political nationalism, triggering the mechanism of global social change. And, on the contrary, political nationalism as an ideology of gaining / restoring political sovereignty triggers xenophobic tendencies and aggressive ethnic nationalism (Mukhametzyanova \& Panchenko, 2018). Although there has been recognition of the importance of examining the indirect effect of perceived parental ethnic-racial socialization on youths' psychosocial outcomes, few studies have done so (Brown \& Ling, 2012). Migration as a social phenomenon attracts attention in times of crisis, in moments of social tension. The problem of migration has become urgent for Russia in the last 10-15 years (Fakhrutdinova \& Kondrateva, 2016). Relevance of organizing socially oriented education is caused by multinational and multicultural society in almost every country nowadays. It assumes the analysis of principles and conditions that allow to construct socio oriented educational process (Maklakova et al., 2019). The strong potential of literature reading as a means for critical thinking development. On the one hand, literature shows the essential traits of the critical thinking, and on the other hand, it is believed to pass the global cultural heritage down through generations. Finally, results of the pre-course and after-course assessment showed the effectiveness of the suggested technology (Asmolov, 2007). 


\section{Methods}

The problem of the conducted research is typical for a number of the research "fields" within certain socio-psychological characteristics of the declared target group can be studied. Accentuating on the most fundamental research, it should be noticed that the study of sociopsychological features of members of teenage youth street criminal groupings is a field of the research of general Psychology, Social Psychology, Sociology, Pedagogy, Deviantology, Criminology, Cultural studies and some other Sciences and disciplines, and possesses multidisciplinary nature . Respectively, it is possible to identify several "concentric circles" with different degrees of generalization, within which the conducted research problem is placed.

Approaches to the study of social and psychological features of teenage youth street criminal groupings (first "concentric circle»):

- system approach (Asmolov, 2007). The system approach allows to study the phenomenon as an integral socio-psychological phenomenon, accentuating on its individual, interrelated elements.

Psychological "middle-level theories" (second "concentric circle»):

- specific theories of deviant and delinquent behavior (V. D. Mendelevich, 2008) (Finckenauer, 2005).

Private research on certain aspects and the identification of individual psychological and socio-psychological characteristics of the personality of adolescent criminals

(third "concentric circle»)

In foreign scientific thought, one should single out a number of works devoted to various aspects of the study of criminal youth groups, which indicates a rather high degree of elaboration of the topic in foreign theoretical and practical discourse. So, in the works of J. Finkenor (Finckenauer, 2005), H. Stridzel (Stritzel, 2007), J. Levine, J. Rabrenovich, V. Ferraro (Levin et al., 2007), and others highlighted the formation and functioning of organized juvenile delinquency, its specificity development in modern European, American, Latin American and Asian societies

Typical perception, acceptance and behavioral attitude of the social environment of the teenagers - members of crime groupings and within the groupings in the conditions of modern society and is, respectively, considered a problem field of the research in Social Psychology. Consequently, the study of socio-psychological features of members of teenage youth street crime groupings is caused by the study of the social and micro-social environment. This shows the need to use a systematic approach in the analysis of the problem.

\section{Results and Discussion}

Experimental part of our research was carried out in the period from 2013 to 2020 in the State government special educational institution for students with deviant behavior of the closed type "Republican special secondary school. N. Ah. Gallyamova» and MBEI "Secondary school №98 (Tatar-Russian)" of Vakhitovsky district of Kazan. 214 schoolchildren took part in the experiment.

Analysis of the data on the method of Mehrabian showed that among the total number of teenage youth surveyed, being members crime grouping, only $16 \%$ have a strong motivation for achievement, or determination for success. $45 \%$ respondents have a strong motivation to escape misfortune; $39 \%$ - do not have a strong motivation, both trends can be traced (see table. 1). 
Table 1.

Results of the experimental study by the method of A. Mehrabian (N=95)

\begin{tabular}{|c|c|c|}
\hline Motivation tendencies & $\begin{array}{c}\text { Number of surveyed } \\
\text { people }\end{array}$ & $\begin{array}{c}\text { Percentage of surveyed } \\
\text { people to the total } \\
\text { number }\end{array}$ \\
\hline $\begin{array}{c}\text { Prevailing of the motivation on success } \\
\text { Prevailing of the motivation of escaping mis- } \\
\text { fortune }\end{array}$ & 15 & 16 \\
\hline Both tendencies can be traced & 37 & 39 \\
\hline Total & 95 & 100 \\
\hline
\end{tabular}

Summing up, the active is the sixth part of all teenagers - members of groupings, they can be considered individuals with a pronounced subjectivity (with a negative (anti-social) vector). It is obvious that this group of teenagers under certain conditions can show leadership qualities and lead others. The opposite group of teenagers, as well as a group of teenage youth who do not have a pronounced tendency of motivation, is guided (led), under certain conditions ready to follow the leaders. It should be stated that the experimental data obtained by other authors in the study of juvenile delinquency who are not members of groupings partially differs from the data obtained in our research of teenage groupings. Thus, in the research of O.L. Panchenko there is a conclusion about the predominance of rather leadership qualities or elements in the examined array of adolescent offenders serving sentences in specialized institutions. Table 2 shows the relevant data.

Table 2.

Classification of respondents on the question: "Which of the statements are closer to you?"(158 people were survied, in \% to the total number of respondents)

\begin{tabular}{|c|c|}
\hline Answer variants & Percentage of surveyed \\
\hline I'm always struggling to be the first in everything & 63,3 \\
\hline I prefer to follow the lieder & 36,7 \\
\hline All respondents & 100,0 \\
\hline
\end{tabular}

The research of the author shows that the paternalistic attitudes ("success does not depend on me") are expressed only by $18 \%$ of teenagers; most respondents rely on their own strength, which also influence on formation of elements of leadership qualities to a certain extent. Thus, our research has shown that there are some motivational differences between teenage youth grouping members and teenagers who are not in groupings. Apparently, this is due to the inclusion of teenagers in groupings: collective actions in them smooth out the motivation to escape misfortune, teenagers with this type of motivation acquire a sense of security, permissiveness, which plunges them into group crimes. This fact is confirmed by the results of the analysis of the biographies of former members of the organized crime grouping. In in-depth interviews, respondents emphasized the group nature of the crimes they committed earlier, citing criminal acts as a sense of security ${ }^{1}$ : "When we went to "work", we were as an integral part. We knew we were a band. We had a... you know, a sense of responsibility for each other or something, and we followed the elders, and they led us, and we weren't scared. We weren't. Although, now I think it is unlikely that we could go alone... the Spirit(courage) is not enough" (Andrew, 38 years old, former member of the OPG. The prevalence of the motivation of escaping misfortune among teenage youth members of groupings over the motivation of success is accompanied by the prevalence of two basic groups of needs, as well as needs for recognition and respect, ac-

\footnotetext{
${ }^{1}$ Hereafter, the original formulation of the respondents ' answers is given in italics and in quotation marks; all names have been changed.
} 
cording to the theory of needs of A. Maslow. According to the results of the method of M. Rogov - A. Gryaznov among the surveyed revealed the predominance of the values of recognition and respect (together - a high rate observed in $44 \%$ of respondents), social values (friendship, family - together a high rate observed in $38 \%$ ) and financial values (together a high rate recorded in $36 \%)$. The data are shown in table 3.

Table 3.

Indicators on blocks of value and semantic orientations in the group of teenage youth - members of groups (by the method of M. Rogov - A. Gryaznov, adapted version; number of surveyed -65 people.)

\begin{tabular}{|c|c|c|c|}
\hline Blocks of values & $\begin{array}{c}\text { Law indica- } \\
\text { tor }\end{array}$ & $\begin{array}{c}\text { Middle indi- } \\
\text { cator }\end{array}$ & $\begin{array}{c}\text { High indica- } \\
\text { tor }\end{array}$ \\
\hline Human values & $16 \%$ & $46 \%$ & $38 \%$ \\
\hline Social values & $46 \%$ & $42 \%$ & $12 \%$ \\
\hline Values of recognition and respect & $27 \%$ & $29 \%$ & $44 \%$ \\
\hline $\begin{array}{c}\text { Financial values } \\
\text { General indicator of value and semantic orien- } \\
\text { tations }\end{array}$ & $22 \%$ & $42 \%$ & $36 \%$ \\
\hline
\end{tabular}

Among the mentioned above blocks of values for teenagers, the most important values are friendship (5.6\%), family (20.3\%), communication among peers $(11.9 \%)$, recognition, respect among peers $(12.6 \%)$, high financial prosperity (14\%), financial prosperity of the family (20.3 $\%)$. At the same time, such values as "interesting work" or "self-development, education" occupy low positions in the hierarchy of values of teenage youth (they were chosen as significant only by less than $1 \%$ of the surveyed); social values in general have the least value and are practically not chosen by the surveyed.

According to the results of in-depth interviews, respondents also stressed the importance of social motives and motives of recognition and respect: "What factors motivated me on participation in groupings (thinks)? I wanted to be "cool", probably (laughs) I like it when school peers look at me with respect, even sometimes with fear!"(Igor, a former member of the organized crime group, 46 years). The conducted analysis of the importance of values showed that the motives of recognition and respect among teenage group members prevail over the actual financial motives. Money and financial values are important from the point of view of the means of realization of these motives. At the same time, it is important to note that money also serves as a means of providing their families, relatives, and much less - for their own (personal) needs (the results of the survey of the surveyed by the method of Rogov-Gryaznov).

\section{Conclusions}

The conducted research has allowed us to come to the following conclusion: social and psychological features of teenagers consisting in groups, are caused by violation of processes of normative socialization, on the one hand, and influence of group as specific closed system, - on the other hand. In turn, the involvement of teenage youth in the group causes a further violation of the process of socialization, leading to deviations in the formation of personal structures.

\section{Acknowledgements}

The work is performed according to the Russian Government Program of Competitive Growth of Kazan Federal University 


\section{References}

Asmolov, A.G. (2007). Psychology of Personality. Cultural and historical understanding of human development" A.G. Asmolov, 3rd ed., Rev. And add. - M.: Meaning: Publishing Center Academy, p. 528.

Brown, M.C., \& Ling, W. (2012). Ethnic-racial socialization has an indirect effect on selfesteem for Asian American emerging adults. Psychology, 3(1), 78-81.

Fakhrutdinova, A. V., \& Kondrateva, I. G. (2016). Contemporary tendencies of social tutoring in period of multiculturalism: moral characteristic. Man in India, 96(3), 853-858.

Finckenauer, J. O. (2005). Problems of definition: what is organized crime? Trends in organized crime, 8(3), 63-83.

Ilikova, L.E., (2016). Migration crisis, the end of multicultuarism and the growth of xenophobia in Germany: a reason hypothesis. Management of Sustainable Development, 3(04), 7277.

Khairutdinov, R. R., Antropova, T. G., Golland, O. N., Mukhametzyanova, F. G., Yarullina, A. S., \& Karimova, L. K. (2018). Comparative perspectives on innovative development of russian economy: Influence of sustainable factors?. Journal of Entrepreneurship Education, 21(3), 1-16.

Levin, J., Rabrenovic, G., Ferraro, V., Doran, T., \& Methe, D. (2007). When a crime committed by a teenager becomes a hate crime: Results from two studies. American behavioral scientist, 51(2), 246-257.

Maklakova, N.V., Khovanskaya, E.S., Favictorovna, A.V. (2019). Critical thinking as a fundamental ability of a personality. Journal of Sociology and Social Anthropology, 10(4), 142-147.

Mendelevich, V.D. (2008). Psychology of deviant behavior. - St. Petersburg: Speech, 445 p.11.

Mukhametzyanova, G.F., Panchenko, O.L., \& Khairutdinov, R.R. (2017). The master's degree as a methodological phenomenon: challenges of modernity. Man and education, 3 (52), 9-14.

Mukhametzyanova, F.G., \& Panchenko, O.L. (2018). Subjectivity in the interdisciplinary discourse field. Kazan Pedagogical Journal, 2(127), 12-16.

Stritzel, H. (2007). Towards a theory of securitization: Copenhagen and beyond. European journal of international relations, 13(3), 357-383. 